\title{
Viewing the body after bereavement due to a traumatic death: qualitative study in the UK
}

\author{
A Chapple, research lecturer, S Ziebland, university reader in qualitative health research
}

\begin{abstract}
Department of Primary Health Care, University of Oxford, Headington OX3 7LF

Correspondence to: A Chapple

Alison.chapple@dphpc.ox.ac.uk

Cite this as: BMJ 2010;340:c2032 doi:10.1136/bmj.c2032
\end{abstract}

\author{
ABSTRACT \\ Objective Whether bereaved relatives should be \\ encouraged to view the body after a traumatic death is \\ uncertain. This analysis of narrative interviews interprets \\ people's accounts of why and how they decided whether \\ to view the body and their emotional reactions to this, \\ immediately and at a later stage.
}

Design In depth interviews with qualitative analysis. Participants A maximum variation sample of 80 people bereaved because of suicide or other traumatic death. Setting Most people were interviewed in their homes. Results For those who had the option, decisions about seeing the body varied. Some wanted someone else to identify the body, because they feared how it might look or preferred to remember their relative as they had been in life. Those who had wanted to see the body gave various reasons beyond the need to check identity. Some felt they ought to see the body. Others felt that the body had not lost its social identity, so wanted to make sure the loved one was "being cared for" or to say goodbye. Some people wanted to touch the body, in privacy, but the coroner sometimes allowed this only after the postmortem examination, which made relatives feel that the body had become police property. Seeing the body brought home the reality of death; it could be shocking or distressing, but, in this sample, few who did so said they regretted it. Conclusions Even after a traumatic death, relatives should have the opportunity to view the body, and time to decide which family member, if any, should identify remains. Officials should prepare relatives for what they might see, and explain any legal reasons why the body cannot be touched. Guidelines for professional practice must be sensitive to the needs and preferences of people bereaved by traumatic death. The way that relatives refer to the body can be a strong indication for professionals about whether the person who died retains a social identity for the bereaved.

\section{INTRODUCTION}

Early in the 20th century it was common to view the body after death, but today in the United Kingdom it is usual to have a closed casket for the funeral, and people may not see the body beforehand. ${ }^{1}$ People may feel ambivalent about the status of the corpse. ${ }^{23}$ They may wish to protect the body yet also fear the corpse because its decay is associated with pollution and disease, and because it is such a powerful symbol of death. ${ }^{45}$ Our society emphasises a need for order, with clear classifications and boundaries, so a corpse may also feel dangerous because it leaks bodily fluids. When bodily secretions are not contained people respond negatively to "matter out of place," as the anthropologist Mary Douglas has shown. ${ }^{6}$

In spite of possible fears, people often wish to see the body of their dead relative. However, nurses may not understand that viewing the body may matter to relatives. ${ }^{7}$ When a traumatic and perhaps disfiguring event has caused death, professionals may be particularly reluctant to allow viewing because they may fear that relatives will have to live with unpleasant, uninvited memories. ${ }^{89}$ There may also be forensic reasons to restrict access to the body. There are no regulations about who is allowed to touch a dead body, but if a criminal offence is suspected most coroners do not allow the body to be touched before the first postmortem examination in case evidence is lost. In 1998, 270 people died when a plane exploded over Lockerbie in Scotland. The procurator fiscal, who has the role of coroner in Scotland, forbade bereaved relatives access to any of the bodies until they had been identified from fingerprints and dental records. Officials then told the funeral directors that it would be better if relatives did not see the bodies. Pamela Dix, whose brother died in the disaster, wrote about her bitter regrets that she was not allowed to make an informed choice about whether to see his body despite the fact that she had been told that her brother was intact and fully recognisable. She wanted to see her brother's body at the crematorium but was told that this was against crematorium regulations and "medically inadvisable."10

Some psychiatrists, such as Worden, ${ }^{11}$ argue that viewing the body helps to bring home the reality of loss, and that viewing helps in the grieving process, because bonds with the deceased need to be severed so that the survivor can make new attachments. Worden suggests that a sudden death in particular, leaves the survivor with a sense of unreality, and that seeing the body can help bring home the reality of the loss. He argues that "letting go" of the deceased is an important part of the grieving process and necessary to the client's wellbeing. Some funeral directors are also convinced that if family members choose to see the body, 
they will find viewing helpful because they will be confronting reality. ${ }^{12}$ Others, including psychiatrists, sociologists, and theologians, have offered an alternative model of grief. ${ }^{13}$ Silverman et al, ${ }^{14}$ for example, argue that, after a death, bonds with the deceased do not have to be severed and that the resolution of grief involves a "continuing bond" which the survivor maintains with the deceased. Thus, different grief counsellors may argue that viewing the dead body (at least once) may help the bereaved, but for different reasons.

There is little evidence to guide professionals working with bereaved relatives after a sudden traumatic death. In a study conducted two years after the Australian Granville train disaster, 36 of 44 bereaved had not seen the body of their relative or friend. ${ }^{15}$ Twenty two of those who had decided not to view the body of their relative or friend had subsequently regretted their decision. Eight people had viewed the body, and only one reported having regrets. Those who viewed the body had better outcomes on a number of measures of psychological recovery than those who did not.

Interesting results emerged from interviews with bereaved relatives after the 1987 Zeebrugge ferry disaster, when 193 people died. ${ }^{16}$ Interviewed between three and 12 months after the event, the group of bereaved relatives who said they had viewed the bodies of the deceased were significantly worse off on measures of distress and anxiety than those who did not view. However, two and a half years after the disaster, results were different. Seventy four bereaved relatives returned a questionnaire. Analysis compared those who had viewed or not viewed the body, according to the time taken to recover the body. Some bodies were recovered from the water the first night, others soon afterwards, and some only six weeks after the disaster, when the ship was salvaged. For the two main groups, where the body was recovered on the first night or on when the ship was salvaged, there were no real differences in overall psychological symptoms or measures of grief, but unpleasant images and thoughts were lower in those who viewed the body. Those who had seen the more damaged bodies were not psychologically worse off. Hodgkinson concluded that those who view may be more distressed in the short term but less distressed in the long term. ${ }^{17}$

Our wider aim in this study was to explore the experiences of people bereaved by a traumatic death. ${ }^{18}$ As is common practice in qualitative research, we examined themes that emerged during the data collection as well as those anticipated. ${ }^{19}$ The issue of viewing the body was raised by the first person who was interviewed. The aim of this paper is to explore and interpret people's accounts of why and how they decided whether to view the body and their reflections on the consequences. The work has clinical relevance because it is uncertain whether relatives should be encouraged to view the body, particularly if it is disfigured. Extracts and further analyses from the interviews can be found on www.healthtalkonline.org (formerly www.dipex.org), a resource based on qualitative studies of people's experiences of health and illness.

\section{METHODS}

In 2007-8, with approval from a multicentre research ethics committee, we invited people to take part in two studies of experience of bereavement due to suicide or other forms of traumatic death. Recruitment packs were distributed via support groups for widows and widowers, general practitioners, a coroner's officer, a police liaison officer, our multidisciplinary project advisory panel, a newspaper article, a local radio programme, a conference about suicide research, the Safer Custody Group, a chaplain, the Centre for Suicide Research in Oxford, and by word of mouth (such as when respondents suggested the study to others). Packs included an introductory letter, information sheet, reply slip, and stamped addressed envelope; those wanting to know more about the study contacted the research team.

\section{The sample}

We aimed for diverse, maximum variation samples ${ }^{20}$ totalling 80 respondents from different social backgrounds and ethnic groups and those bereaved due to different types of suicide and traumatic death. We could have interviewed a smaller sample at different points in time (a qualitative longitudinal study) but chose instead to seek a broad range of experiences by interviewing those bereaved many years ago and others bereaved more recently; those bereaved in different circumstances and with different relations to the deceased; and people who lived in different parts of the UK; with different support systems and coroners' procedures (see tables 1 and 2 for more details).

One of the authors $(\mathrm{AC})$ interviewed people in the setting of their choice (usually their home) for between two and six hours. Interviews were long, partly because people wanted to talk, but also because the interviewer would suggest a break if someone became distressed. Having signed a consent form, people were asked to talk about their experience of bereavement; they were told they could stop the interview at any time. In the first, open ended narrative, a section of the interview respondents described what had happened. When the narrative was finished, a semi-structured interview guide with prompts was used to explore any relevant issues that had not already emerged. The interviews were all audiotaped, fully transcribed, checked, and then returned to the participants so that they could read the text and modify it if necessary.

At this stage participants were asked to sign a copyright form giving us permission to use the content of their interview on our website and in publications, research, education, lectures, and broadcasting. They also signed another form which indicated the name they wished us to use on the website. Most people decided they wanted us to use their real first name. A few chose a pseudonym.

\section{Analysis}

We read and re-read the data, constructed a coding frame, coded the data, and then examined themes 
Table 1| Sociodemographic characteristics of the 80 bereaved participants

\begin{tabular}{|c|c|}
\hline Characteristic & No of participants \\
\hline \multicolumn{2}{|l|}{ Age at time of interview (years): } \\
\hline $22-40$ & 18 \\
\hline $41-60$ & 45 \\
\hline $61-84$ & 17 \\
\hline \multicolumn{2}{|l|}{ Sex: } \\
\hline Men & 25 \\
\hline Women & 55 \\
\hline \multicolumn{2}{|l|}{ Relationship with deceased: } \\
\hline Child (who lost a parent) & 9 \\
\hline Brother or sister & 12 \\
\hline Partner, husband, or wife & 16 \\
\hline Parent (who lost a child) & 38 \\
\hline Friend or distant relative & 5 \\
\hline \multicolumn{2}{|l|}{$\begin{array}{l}\text { Occupation (or previous occupation if } \\
\text { retired): }\end{array}$} \\
\hline Professional & 47 \\
\hline Other non-manual & 21 \\
\hline Skilled manual & 3 \\
\hline Unskilled manual & 1 \\
\hline Other (such as housewife or student) & 8 \\
\hline \multicolumn{2}{|l|}{ Ethnic group: } \\
\hline White British & 70 \\
\hline White German & 1 \\
\hline Indian & 4 \\
\hline Afro-Caribbean & 4 \\
\hline Afro-Caribbean/white British & 1 \\
\hline \multicolumn{2}{|l|}{ Time since bereavement: } \\
\hline 4 months- 3 years & 35 \\
\hline$>3$ years -9 years & 22 \\
\hline$>9$ years & 23 \\
\hline
\end{tabular}

across the whole dataset as well as in the context of each person's interview. We paid attention to the language that people used during the interviews - for example, noting whether people referred to the dead body by name, as "him" or "her," or as "the body" or "it." A qualitative interpretive approach was taken, combining thematic analysis with constant comparison. ${ }^{2122}$ NUD*IST, QSR N5 (a qualitative data indexing package) facilitated the analysis. ${ }^{23}$ Both authors read the relevant QSR N5 reports and regularly discussed coding and interpretation of results. Symbolic interactionism was a conceptual framework that helped with the interpretation of the data (see box). ${ }^{24}$

\section{RESULTS}

We first draw attention to the language that people used in discussing the body of the person who died and then explore the reasons why people said they had decided to view the body and how they reacted to seeing the body (see table 3). We then consider the accounts of those who decided not to view the body, and finally the few people for whom circumstances meant that they had no choice about whether they saw the body.
Perceptions of the body and language used to describe it Some people described the body as an empty shell, even relatively soon after the death. They described the body as "it" or "the body." Michael, for example, whose friend had died by suicide, talked about seeing "the body." He said that viewing the body had brought home the reality of death. Others seemed to regard the body as still having social identity, and they talked about the body as "Tom" or "Jon," "him" or "her." Some people (as Valentine found in her research ${ }^{25}$ ) talked about the body differently at different times and in different settings. Dolores, for example, saw her son soon after he was murdered and again 10 days later. When she talked about seeing her son soon after death she spoke of "him," but when she described the body 10 days later, she explicitly described it as "just a body":

Dolores: He was stabbed, and I just said, "I want to see him now, I want to see him now" [crying] (...) We [also] went to see him just before he went into the coffin (...). But that time it wasn't Tom, he didn't look like he did the first day [crying] Interviewer: Do you regret going to see him again then, or was it the right thing to do?

Dolores: No, it was OK, but I knew it wasn't him. It was just a body. Then you know his features changed. Now 10 days, it's a long time.

Jayne referred to her murdered husband as "Jon" at all times, but her view of his body seemed to shift over time. Recalling events of 16 years ago, she said that when she saw him at the hospital, soon after his death, she "saw a young man who was dead." Although she knew he was dead, she said she talked to him and sang to him (see quote below where people talk about caring for the dead). However, later when she went to the mortuary, he was behind a glass screen and he looked different. His eye socket looked flat, which Jayne thought was due to the postmortem examination. Jayne said that she felt that Jon had "left his body": Jayne: I remember looking at Jon and saying, "He's not there anymore." Because he looked as if he wasn't in his body anymore. Something had happened, and I'm not a religious person. I'm spiritual but I'm not religious. But it struck me when I saw Jon the second time that he wasn't there. His body was there but Jon wasn't there.

Underlying assumptions of symbolic interactionism According to Blumer, ${ }^{24}$ symbolic interactionism rests on three premises:

- That people act toward things on the basis of the meanings that the things have for them

- The meaning of such things is derived from, or arises out of, the social interaction that one has with one's fellows

- These meanings are handled in, and modified through, an interpretive process used by the person in dealing with the things he or she encounters 
Table 2 |Means by which the 80 participants were bereaved

\begin{tabular}{ll} 
Means & No of participants \\
\hline Bereavement due to suicide & 11 \\
\hline Hanging & 8 \\
\hline Jumping & 6 \\
\hline Motor bike or car fumes & 3 \\
\hline Drug overdose & 3 \\
\hline Car crash & 2 \\
\hline Suffocation & 2 \\
\hline Shooting & 2 \\
\hline Standing or driving in front of a train & 1 \\
\hline Drowning & 1 \\
\hline Help from Dignitas & 1 \\
\hline Burning & 17 \\
\hline Bereavement due to other violent death & 6 \\
\hline Murder or manslaughter & 5 \\
\hline Road crash, as driver/passenger & 5 \\
\hline Road crash, as pedestrian & 2 \\
\hline Bomb explosion & 2 \\
\hline Railway accident & 3 \\
\hline Industrial explosion & \\
\hline Fire related death & \\
\hline
\end{tabular}

Days later, she saw Jon again in the chapel of rest. This time the funeral director had applied makeup to his face. Jayne's perception of the body seemed to have changed because at that stage she said that she could say goodbye:

Jayne: So when I went to see him in the chapel of rest, I suppose because he had makeup on, I was able to say goodbye to the man I loved (...). I was able to touch him, and have a conversation with him, and tell him I loved him, and tell him what songs we were having at his service.

Reasons people gave for wanting to see the body Several respondents had been asked by police officers to identify the body; some relatives thought (mistakenly) they had to do this, while others wanted to see

Table $3 \mid$ Details of whether, and how, the 80 bereaved participants chose to see the dead body and their reactions to seeing the body

\begin{tabular}{lc} 
Details & No of participants \\
Found the dead body (after a suicide): & 6 \\
\hline Chose to view the body again later (and were glad they did so) & 3 \\
\hline $\begin{array}{l}\text { With the person in intensive care or at the time of death (did not } \\
\text { see the body again later) }\end{array}$ & 6 \\
\hline Not given an opportunity to see the body & 11 \\
\hline Chose not to identify or view the body & 8 \\
\hline Chose to identify or view the body*: & 49 \\
\hline Said this was the right thing to have done & 35 \\
\hline Seemed to have mixed feelings about this & 9 \\
\hline Regretted seeing the body & 2 \\
\hline Did not comment on their feelings about this & 3 \\
\hline
\end{tabular}

This is a numerical breakdown of a qualitative sample selected for diversity and is therefore not intended to be numerically representative of the population.

*Body in a hospital ward, mortuary, or funeral director's chapel of rest. the body of the person they had loved. People often gave more than one reason for viewing the body.

It was also clear from the accounts that husbands, wives, and other family members did not always make the same decisions about viewing. Bob, for example, wanted to see his son's body after his death by suicide, but his wife decided not to; Rachel identified her son, but her husband and daughter chose not to see his body.

\section{To make sure there had been no mistake}

Some respondents said that they had wanted to identify the body to make sure there had been no mistake. Rachel's son, Dave, died in Iraq in a bomb explosion. When his body arrived back in England, the coroner's officer asked her if she could help with identification. Rachel could identify him from his tattoos. She wanted to make sure that it really was her son's body:

Rachel: First thing the following morning, we went up there, because I had to identify the body, and obviously he had a couple of tattoos, so he was quite easy to identify and she asked me what the tattoo was, and I told her. And she obviously had his passport with them, and she showed me the picture in the passport and asked me, "Was that my son?" Interviewer: Was this the coroner's officer? Rachel: Yes it was. And I asked her, she had obviously been involved in cleaning him up, because she said she had been involved in that, and I did ask her, "Would I recognise him?" And she said, "No, I don't think you will." And that was a bit of a, a shock because she said, "I don't think, he doesn't look like he does on that passport," is what her words were. And then I went in to identify the body.

Interviewer: Were you on your own?

Rachel: Yes. Yeah my husband and my daughter didn't want to go in. And they never did go in. So, they didn't want to.

Interviewer: Was it the right thing for you to go and see him?

Rachel: Most definitely, yes, yes, I had to make sure that that was my son, because you know, they might have made a mistake.

\section{To care for the dead}

People often said that they wanted to reach their dead relative as quickly as possible to see if there was anything that they could do or to make sure their dead relative was "alright." Some families had to wait a day or more before seeing the body because the coroner wanted forensic evidence undisturbed before the postmortem examination. Often the police officer or the coroner's officer insisted on observing the viewing, again for forensic reasons. Delays and lack of privacy could be distressing. When describing events that happened immediately after the death, those who wanted to care for the dead invariably used their relative's name or talked about "him" or "her" rather than "the body" or "it." A man with schizophrenia stabbed 
Jayne's husband in an underground station. After Jon died in hospital, Jayne said that she talked to him, reassuring him that he was not completely on his own.

Jayne: And when they took me into Jon, where Jon was laid out, you know, he was in a room on his own and I think my, my over-riding feeling was that I didn't want Jon to be frightened (...). I know it's going to sound a bit silly, but I think the over-riding feeling was that I wanted to share, I can't say share what he was experiencing but be there with him so that he wasn't on his own. So I talked to him a lot, and I reassured him that he wasn't on his own, and sang to him.

Mothers in particular described wanting to retain their role as a caring parent. After Elizabeth's daughter, Marni, had died in a car accident, the police told her that Marni had "not survived," but she wanted to reach her daughter quickly:

Elizabeth: I just wanted to get to her straightaway because I felt that there was something I could do, you know, that's what every mother feels, isn't it, you can always do something to make it better (...). Interviewer: And was that the right thing for you to do to go and see her?

Elizabeth: Yes, definitely, definitely. I, yes I

couldn't wait to get to her.

Pat's son had died one and a half years ago when his motorbike hit a car. She was upset because delays had occurred before she could reach him and because the coroner's officer did not allow her to be alone with her son.

Pat: It was eight hours before I was able to see him, and I wished that it had been a shorter period of time. I think, as his mother, I wanted to be with him, and of course we want to be with our, our children through their important experiences. (...) But of course the coroner's officer, and I guess it's a rule of some sort, but she came into the place with me and was standing on the other side of a glass, a small glass screen where she could see me the whole time. So I wasn't allowed to be with Matthew, with my son on my own. And I am sorry about that and I don't understand why it is that a mother cannot be with her child on her own if that's what she wishes. I don't understand why I could not have washed him, I could not have dressed him, I could not have looked after him (...) it feels like the organisation, the state, whatever it is, the police authorities, had taken my son and were doing with him what they felt best to do. And I was suddenly an outsider and not able to do things for my son (...) It felt as if he was somebody else's property and I had to ask permission to go and see him. And I had to be observed whilst I did.

Both Elizabeth and Pat's accounts suggests that after their children died their bodies had not lost their social identity. Pat talks about people wanting to be with "their children through their important experiences" (although few parents expect their child to pre-decease them). Both Turner and Howarth explain why boundaries between the living and the dead may seem blurred. $^{2627}$ Turner argues that "consciousness also involves embodiment. I both have and am a body."

Margaret's daughter hanged herself in prison. Margaret wanted to get there as quickly as possible. She did not want to wait for the funeral director to make the body look presentable. Her account is interesting because it seems that she feared that her daughter's spirit had not left the body - that "lingering energy" was still around.

Margaret: Then coroner's officer said, "We can't stop you, we can't prevent because that's your right. But we would strongly advise that you wait until the funeral director has seen to your daughter before you see her." And I can remember saying, "Well she's my daughter, she doesn't need to look pretty, I need to hold her." (...) I was terrified that she might still be lingering around her body in a confused state because of the suddenness of the death.

Interviewer: Hmm.

Margaret: I really do believe that that's the least auspicious way to die. You know, like at the moment at death that you're in this pain and confusion and ...

Interviewer: Hmm.

Margaret: ... on your own. And so I needed to get there so they could shift the energy on for her, if it was still lingering.

Margaret wanted to make sure her daughter was "warm" for the funeral, so she bought a coat with a fur lining in which to dress her daughter's body. This act suggests that, to Margaret, her daughter remained very much a person and that her body retained its social meaning after death. ${ }^{24}$

\section{To say goodbye}

Helen's daughter, Charlotte, died when she took an overdose of heroin. Helen said that it was important that she saw Charlotte after she died so that she could say goodbye:

Helen: I felt at the time, and I still feel, that it was the most important thing that I needed to do [see Charlotte] (...). I would've regretted for the rest of my life if I hadn't have done that. (...) I sat next to Charlotte for, I don't remember, maybe 15 minutes, and I spoke to her. I think it, it was more important than at the funeral, saying goodbye actually, because she, I could see her.

\section{Imagined images might be worse}

Marion's husband killed himself through carbon monoxide poisoning in 1996. She went to the mortuary to identify his body. At first she did not recognise her husband because the body bore no resemblance to the man she remembered. Despite this traumatic experience, she returned to view his body on two occasions with her four children, aged between 10 and 22 .

Interviewer: And looking back, was it the right decision, to give the children that choice? 
Marion: I think so. I don't remember asking them if they wanted to [see the body]. I remember them telling me they wanted to. I don't know whether I'd have had the courage to ask them to be honest, but they both said, "Where is he? What's happening to him and what does he look like?" And then the older, the middle one saying, "Well I want to see him." And then the other one of course said, "Well I do as well." [laugh] Not to be left out. I know my, my parents particularly were absolutely horrified that I'd allowed them to do that. With the benefit of hindsight I would do it again. It would never occur to me now not to. Afterwards I thought, "Oh I shouldn't have done that. The trauma of them seeing him like that," but maybe the trauma of what they would have imagined would have been worse.

\section{A sense of duty or an obligation}

In some religious traditions there is a duty to wash the body, or there is an open coffin before or during the funeral. After Kavita's brother died by suicide (jumping), her father helped to wash and dress the body, according to Hindu tradition. Kavita saw her brother's body when it was in an open coffin at home.

Kavita: My dad was very helpful in, in terms of sorting my brother's body out and washing and getting the clothes ... all these sort of things.

Interviewer: Is this a Hindu tradition, washing the body?

Kavita: Washing the body and dressing the body in a new ... I think it's a new outfit (...). And I just remember my dad coming home from, from bathing my brother, coming home and saying, oh, he started talking about his hand and his foot that had been broken. And obviously that kind of stuck in my mind too.

Interviewer: $\mathrm{Hmm}$.

Kavita: We did see that actually because we had an open coffin in the house, that's also a cultural thing.

Religious tradition may not be the reason for this sense of obligation. Amanda's husband identified their son, Lori. Amanda did not see Lori immediately because she had never seen a dead body before and she said she felt frightened. However, four days later she decided to view Lori's body, partly because she said she "owed it to him."

Interviewer: Did you have to go to identify his body?

Amanda: My husband chose to do that. I did see Lori when he was in the, the casket, (...) I didn't go and see him [to do the identification] in that I was actually quite frightened (...). I am pleased I went, because that way I, I can never lie to myself that he's not dead. I felt I owed it to him [crying].

As noted earlier, the boundaries between the living and the dead are often unclear. People may invest the dead body with continued social meaning. ${ }^{24}$ Baglow suggests that "the family, in claiming the corpse of a family member, is actually fulfilling an obligation to that corpse, rather than asserting rights of 'ownership' over it." ${ }^{28}$ Amanda's account, above, suggests this sense of obligation.

Patricia's husband, Andrew, died in a fume-filled car. She felt it was important that she rather than anyone else identified him because it was a way of "bringing him back into the family" and because she felt it was right, even though she also described it as one of the worst things she had ever had to do:

Patricia: One of the first things I said to the police officer was, "How, why, where, when?" And, and then I said, "I must go to him." [The officer said], "Oh, well, we can get somebody else to identify him. You don't have to do it." And I said, "No, no, no, it must be me." (...)We don't know if he died before midnight or after midnight, but it will have been dark, cold, alone, away from his family, and I felt it was so important that I went to identify him because it was like bringing him back into the family. It was one of the worst things I've ever had to do in my life. It was not an experience I would wish on anybody. But I know it was the right thing that I did it and not somebody else.

\section{Reactions to seeing the body}

Motivations, expectations, and reactions are linked and differed between families and deaths. Seeing the body might upset some family members more than others and, as we have shown, sometimes different members of the family made different decisions. Almost all of those who chose to see the body said that they had made the right decision, even if they had seen injuries, bruising, or signs of decomposition. Rachel, for example, who saw her son's body after it came back from Iraq, said that she had been right to see his body in spite of his injuries. She saw her son many times before the funeral.

Rachel: ...even though he had lots of injuries and, you know, he had a massive like head injury and had snapped his leg, and all down his left side was completely injured, sort of squashed was a better word for it, [um] but it was still him. And even after a week being in Iraq it was still Dave.

Interviewer: $\mathrm{Mm}$. So it was the right thing to go and see him?

Rachel: It was definitely the right thing to go and do, yes, definitely.

Two of Kate's daughters took their own lives by hanging. Izzy died in 2006 and Anna died in 2007. The funeral director advised Kate not to see Izzy's body, but Kate said that she made the right decision to see her daughter:

Interviewer: Did you actually go and see either of the girls' bodies after they died?

Kate: Oh gosh, yes. [laughs] Yes.

Interviewer: Was that a good thing to do?

Kate: For me, oh absolutely for me, totally. I

dressed, I put my wedding veil on Izzy and quite a bit of jewellery and all her bits and pieces. And we had a coffin. The coroner said to me, because Izzy had been there for a few days she ... there was quite 
a bit ... she was decomposing. And they advised us not to see her. And I said, "No." But my sister who, who organised all the funerals, said, "Don't worry, don't worry, Kate, we will make her presentable." Interviewer: So you did look at her?

Kate: Oh yes. She had lots of makeup on.

\section{Relieved to see the dead person at peace}

Some, particularly those who had lost a relative through suicide, said that they were relieved to see their loved one looking peaceful after all the stress or unhappiness they had experienced before their death. Susan X's reaction to seeing the body of her son, Barry, is an example of this:

Susan: One consolation for me was that Barry looked so peaceful, like all the anger had gone, all the stress, the worry. He really did look lovely, and he looked at peace and I think that helps a lot, when you see them like that. You know, and for me, also, I didn't have to worry what he was going through.

\section{Accepting the reality}

Viewing sometimes helped people to accept the reality of the death. Sarah's husband, Russell, died in a hospital operating theatre after a road crash. Initially, she did not want to see him after he died, but on reflection she said that it was important that she had seen her husband in the hospital because until then she had not believed that he was dead:

Sarah: The fact that having actually seen him dead is the reality check that makes you realise, "No this is the real world, he has gone." (...) It's part of being able to believe that he is dead because if I hadn't seen him I think the being able to believe he is dead would have been much harder.

\section{Mixed reactions}

Some people said that at first they found the appearance of the dead body upsetting or reported that they had mixed reactions. Linda, for example, was upset when she first saw her daughter's body because she had expected the body to look pinker. However, when it had "sunk in that the body was not going to look the same" she decided to return several times to make sure her daughter was "OK":

Linda: And when we got out of the funeral director's, I said to my husband, "How could you say she looked nice? She looked awful. Didn't, didn't look like her at all." And he said, "Well, what was you expecting her to look like?" And I said, "Well, I was expecting her to look pink, like pinker, and like more like when she was alive." And he just said, "Well she's not alive."

Interviewer: Would you recommend to other people that they didn't go and see their loved one after they'd died?

Linda: No, because I went after that. I kind of, when he said that it kind of sunk in that, you know, she wasn't going to look the same. But we did go and see her quite a few times after that. Yeah.
Interviewer: And was that the right thing to do? Linda: Yeah, I think so. Yeah, we went in [um] we took some things in, took some [um] photos and things like that for her (...) But I wanted to go and make sure that she was OK really.

Martin's wife, Steph, died when a bus hit her while she waited on the pavement. He went to the hospital to identify his wife, and was shocked to find that her body was so cold. Talking about the body, he said that "it wasn't Steph ... she had already gone". Viewing his wife's body did not compare with the shock of witnessing her fatal accident.

Martin: Her face, from the mouth up to her nose, was black and blue. (...) I think that the tyre had gone over her face basically, and I just held her hand and I was absolutely shocked at how cold it was $(. .$.$) .$

Interviewer: Would you rather have not gone? Martin: No, it's not affected me actually, it hasn't, it hasn't affected me that much. I don't have nightmares about it (...)

Interviewer: But, looking back on it, would you have rather somebody else had identified her, would you rather not gone to see her?

Martin: I wouldn't, well I mean I'd had that shock of seeing her under the bus, nothing will ever compare to that (...).and it [the body] wasn't Steph to me, she'd already gone. She'd already gone, you know, she was dead and this was just something that I wanted to do, I wanted to be involved as much as I could, in all the legal things.

Marcus identified his fiancée, Louise, after a man had stabbed her to death. He wanted to see her again eight weeks later, before her cremation, so that he could say goodbye. Looking back, he said that he was pleased that he had seen her face, in spite of the bruising, but he wished the funeral director had prepared him better.

Marcus: Louise's face was very badly bruised, and it was so many different colours. And her hair was sort of matted. They tried their best to make her look like we remembered her. But it didn't ... it wasn't her (...). If you can imagine this is after a number of weeks, almost months, she was a lot of different colours. She was black, green, brown, purple. And I kissed her on the forehead, and, and said goodbye that way. So for me it was...

Interviewer: What would you've liked the funeral director to have said?

Marcus: I guess in a way it would've been good if he'd said, "She's not going to look how you remember so please take that into consideration," rather than just let me in. I suppose in, in looking back I might've known what she was going to look like. I'm not, I'm not silly or stupid. But I thought she might look a bit more, I don't know, like how she used to look asleep. But she didn't.

Interviewer: Are you glad you saw her?

Marcus: I wouldn't change that for the world. I'm pleased I saw her. And I'm pleased in a way I could 
only see her face and not all the brutality that had happened to her.

Jenny's husband, David, jumped to his death. She went to see him in the hospital mortuary. She said that she "knew instinctively" that it was the right thing to see his body and that, although she felt distressed when she saw him, she also felt comforted. She did not see his injuries because most of his body was covered when she got there.

Jenny: And I did go and see his body. Again that's something that I absolutely, utterly had to do and spent, I think, about the best part of an hour there with him. And that was both upsetting and comforting. So I talked to the coroner a little bit. I knew that he [David] had internal injuries, but I didn't see that. I just saw his face and his hand (...) But for me it was definitely right to go and see his body.

Erykah also reported mixed reactions after she saw her brother in an open coffin the night before his funeral. She was ambivalent about seeing him because blood started to flow from his neck as the body thawed.

Interviewer: So was it good for the family to have an open coffin with him in the house?

Erykah: Yes, yes. It was a bit strange, because I examined him, it was really bizarre, it was good [having an open coffin], but I don't know if I'd choose that again because his wound, he got shot in the neck. He got shot eight times, nine times he got shot (...) but they shot him in his neck at close range, and because he'd been brought out of the fridge. I don't know why this was but the wound was still bleeding, I think it was because he was thawing out, so his shirt, blood started to show up in the shirt, which was a bit weird, you know?

Erykah found the sight of seeping blood "bizarre." Changes in the body after death can cause alarm and distaste, not least because in our society blood, mucus, and excreta are viewed as the body's most dangerous polluting products. ${ }^{4}$

\section{Regrets about seeing the body}

Sally deeply regretted having to view her mother's body after she died in a fire. A police officer asked Sally and her brother to go to the hospital ward to identify her mother's body; her brother initially offered to do it, but when he could not recognise the body Sally reluctantly agreed to do so.

Sally: So then they asked us to identify her, and I said I can't, because they said she'd had black soot all going in her mouth and she didn't look particularly, and I said, "I can't do it," so he [my brother] went in but he, he couldn't recognise her. He said, “I can't, I don't, it doesn't look like Mum, that's not Mum."

Interviewer: Aah.

Sally: So I had to go in to formally ID her, because he couldn't ID her.

Interviewer: Oh no.

Sally: Because he said it looked nothing like her.
Interviewer: That must've been awful.

Sally: So, yes, so I had to, I saw her and I knew it was her and I just literally, one second and then, because I just thought I can't have that look, that thought, in my head all the time of her. And I think that was probably the worst part, I think of the whole scenario actually, was actually seeing her. I wish I hadn't done that, that was the worst experience of it was actually, and I don't, I, personally I'd never do that, I'd avoid seeing any dead body because I think that was awful.

Once in the funeral parlour, Sally's mother's body was embalmed. Other members of the family wanted to view the body so Sally paid a hairdresser to do her mother's hair. She also bought makeup so that the mortician could make her mother look better. Both Sally and her brother returned to the funeral parlour to view her mother's body once more. Sally said that she decided to view the body again because she wanted to erase the horrible memories she had of her mother's soot covered face. Her brother felt comforted by what he saw, but Sally did not:

Sally: No, none of it helped. Because, you know, they done her hair, but it's not how she had her hair. They done her makeup but it's not how she does her makeup. You know they, I knew what colour she wore, and I said, "She always wore makeup. She always made an effort with her hair and her makeup, always made an effort," so, but it wasn't like, she, but she just didn't look like her. She looked really hard and it just looked awful, it was awful. Didn't like it (...) It wasn't any better. That's why I've got her photograph and I just look at that, and I say, "That's how I'll remember her."

Angela regretted viewing the body of her friend who was badly bruised having been stabbed to death. Angela said that she should not have seen "the body" because she could not recognise it and it felt alien.

Angela: ...that's one thing I probably shouldn't have done.

Interviewer: Why?

Angela: Because doing that, it didn't prepare me, I've seen dead people before, you know [um], but she just wasn't the woman I knew, I didn't recognise this person in front of me whatsoever. [Um] she was bruised, she was, and I just thought, I kind of felt dead inside, I just kind of felt like, "Oh who is this, this is not my friend." (...) I could not recognise the body in front of me. It was the wrong thing for me to do because I was just looking at this person, thinking, "Who are you?" It felt like a bit like an alien had invaded somebody's body; do you know what I mean? It just, I couldn't, you know, it just did not look like [my friend].

The accounts given by Sally and Angela differed from many others in this analysis in that they described regret about seeing the body. ${ }^{29}$ In both cases the bodies were damaged and hard to recognise, and in Sally's case she had viewed her mother's body only reluctantly (that is, she had not truly chosen to see the 
body). Some of the distress might have been avoided if Sally's mother had been identified by another means (such as dental records) and if Angela, in common with some of those with mixed reactions, had been better prepared for her friend's appearance.

\section{Those who had decided not to view the body}

Eight people could have seen the body of their dead friend or relative but had not done so or had made an active decision that it was not the right thing to do. Susan Y, for example, had not seen her father's body after he jumped over a high cliff. Her brother identified the body, and her account ("I don't think I would have wanted") suggests that she did not really consider going to see his body at the hospital:

Susan: He was brought back to the local hospital where my brother identified him, I think. I mean he was completely, everything was crushed, I think, hardly recognisable.

Interviewer: So you didn't go and see him? Susan: No I didn't. I don't think I would have wanted to actually, because he was a very large man, larger than life in every single way, and I don't think I would have wanted to see him like that.

A police family liaison officer invited Rosemary to identify her son's body after he was killed in the London bombing of 2005. She decided that it would be better if he was identified by DNA, but when she was interviewed four years later she wondered if she had made the right decision:

Rosemary: My sister-in-law, who has been involved in this kind of area, said, 'Don't, definitely don't [identify the body] because you don't need to do that, and in the circumstances it will be an appallingly difficult thing for you to do.”(...) But I still wonder, if I'm really honest, whether I should have done [identified the body] but I'm not sure that, I don't know, I'm ambivalent about it because part of me feels that; it's not closure, because it's not about that where I'm concerned, it's about understanding the reality of what happened and I'm not sure that if you don't do that [identify the body] whether you really do. (...) My feeling still is that we made the right decision because that isn't the right way to remember somebody, I don't think, it really isn't.

Karen could have identified her mother's body after she died in a fire, but at the time she decided that it would be better if her mother were identified using dental records. However, like Rosemary, she felt ambivalent about the decisions she had made. She recalled that at the time of her mother's death she wanted to know whether her mother had died peacefully.

Karen: Half of me wishes I had gone and done the ID myself. (...) Sometimes she [the police liaison officer] was a bit edgy, and I thought if I had done the ID myself I'd have had a lot more questions answered, rather than having someone else tell me, that you don't know from Adam, and then feel, yes, they are protecting you from it. Some people need to know more than others.

Interviewer: So you wanted to satisfy yourself that she died peacefully?

Karen: Yes, I mean now [after the inquest] I don't think she did.

Many factors may have influenced people when they made the decision not to view the body of their dead relative. The circumstances surrounding the death and other people's opinions were often influential in decisions not to view, as well as in decisions to see the body.

\section{Lack of choice in viewing the body}

Respondents who had found the body (such as after a suicide at home) clearly had no choice about whether or not to see it. A few had been children at the time of the death, and their remaining parent had not given them the option of seeing the body. Others had not been able to see the body for a number of reasons, including the opinions of officials or the requirements of official investigations. Steve, for example, wanted to see the remains of his dead sister after she stepped in front of a train, but the coroner allowed him to see only some photographs. Steve said that he wished the coroner had allowed him to make an informed choice because he thought that if he had seen his sister's body it would have helped him in his grief and would have made it easier for him to accept her death. Another man said that after his brother died in the Bali bomb of 2002 he had not seen the body because within a few days the Foreign Office and the Indonesian coroners declared that they would permit no visual identification because the bodies had deteriorated.

\section{DISCUSSION}

This study shows that, even when a death has been traumatic and the body injured, bereaved relatives may have many reasons for wanting to see and touch the body as soon as possible. Some wanted to confirm there had been no mistake, and that their friend or relative was indeed dead. A few felt an obligation-that they ought to see the body or wanted to care for the body or say goodbye. Those who had made a choice (either to see or not to see) usually said that it had been the right decision for them, even if they had had mixed reactions or felt some initial distress. The study underlines the importance of making it clear that there are other ways of identifying the body, offering a choice, recognising that different members of a family may make different decisions, and preparing the relatives for what they might see. The way that relatives refer to the body can be a strong indication for professionals about whether the person who died retains a social identity for the bereaved.

Both models of grief, discussed in the introduction, seem relevant to our findings. Viewing the body may have helped some in the grieving process because it brought home the reality of loss, ${ }^{11}$ which may have helped people to make new attachments or plans for the future. For others, viewing seemed to help because 


\section{WHAT IS ALREADY KNOWN ON THIS TOPIC}

There is uncertainty about whether to encourage bereaved relatives to view the dead body after a traumatic death

The few studies that have been done suggest that if people choose to see the body they may benefit, particularly in the longer term, but there has been little research on reactions to the appearance of the body

\section{WHAT THIS STUDY ADDS}

This qualitative study helps to explain why people bereaved by a sudden and traumatic death think it is important to see the body of their dead relative or friend

Seeing a damaged body is inevitably distressing, but in the study was rarely regretted. Those who had mixed feelings or regretted seeing the body felt they had lacked choice or preparation

Clinicians should not assume that relatives will be harmed by seeing a bruised or damaged body. Within a family there will be different attitudes; some bereaved relatives may want to view, but others will not, and some will find viewing helpful, but others may find it distressing

The way that relatives refer to the body can be a strong indication for professionals about whether the person who died retains a social identity for the bereaved

the resolution of grief involved a "continuing bond," which the survivor maintained with the deceased. ${ }^{13} 14$

Our study is important because so little has been published about people's reactions to identifying or viewing a dead body, particularly after a traumatic death, and professionals need more evidence to guide them. The people we interviewed had more to say about the appearance of the body than has been reported previously. ${ }^{30}$ The interviewer did not press respondents to describe the appearance of the body, but they sometimes described in detail what the person had looked like after death. The study also sheds some light on how families decide who should view the body: families need preparation and reassurance that they do not have to identify the body if they do not want to.

Our study has its limitations. As with any qualitative study aiming for a maximum variation sample, the findings are not intended to be numerically representative - the sampling method is intended to show the diversity in responses, including those that are less usual. We emphasise that a detailed numerical analysis of the results would not be appropriate. People often decided within families who should view the body; it is quite possible that those who viewed the body may also have chosen to take part in the interview for this study. We mainly interviewed white British people living in the UK. Our respondents were mainly professional people, and, although we interviewed more men than several other studies of bereavement, there were twice as many women as men in the sample. Attitudes to death and funeral practices vary enormously by culture and religion, and we would surely have heard additional perspectives if the study had included a broader social and ethnic diversity. ${ }^{31}$

No account is static-people's views and interpretations of their experiences are likely to change over time and with the telling. People seek to make sense of unpleasant events and justify their own responses, to themselves and others. Marion, for exam ple, said that soon after she had taken her children to see their dead father she felt she had done the wrong thing. It was only later that she decided that she had been right to take her children to see their dead father because seeing him was probably less traumatic than images her children might have imagined. This fits in with findings described in the introduction, that after the Zeebrugge ferry disaster, people who saw the bodies were more distressed in the short term but less distressed in the long term.

Our findings have clear implications for healthcare professionals, counsellors, coroners' officers, police officers, and funeral directors. Professionals could help bereaved people to make this decision by telling them what to expect to see if they view the body, and then give them time to think about their decisions. A personal account given by Sheila Awoonor-Renner in the $B M J$ parallels the experience of the bereaved parents interviewed in this study. ${ }^{32}$ She was devastated when her 17 year old son died in an accident and emergency department. She stresses that after any death in the emergency room as much decision making as possible should be given back to the parents, and that the first question should be, "Would you like to see her immediately?" and the next, "Would you like to wash her?" She explains that this approach communicates continued ownership to the parents, namely, "She is still your child, you can still care for her, you can still touch her." She also writes that professionals must allow parents to change their minds. These views resonate with the views of some of the people we interviewed, who said that they still wanted to care for the deceased.

Our findings suggest that there is considerable diversity within families with regard to viewing the body (as well as within cultures or subcultures). The relationships that existed before the death affect how the body is seen and the meanings with which the body is invested. ${ }^{24}$ Within families, one person might decide to view and touch the body, to clothe and care for it, while other close relatives prefer not to. Stroebe et al argue that we must recognise the enormous variations in forms of bereavement. ${ }^{31}$ They suggest that, "On the therapeutic level, this would mean curtailing the search for ideal therapeutic procedures and focusing instead on tailor-made treatments. This would require highly sensitive receptivity - an open listening to the client voice, for the reality and values of its sustaining subculture. At the same time, this option would invite educating for alternatives" (page 42).

This recommendation must surely apply to viewing the body. People need to know that they do not have to identify the body and that identification is possible with DNA or dental records. If touching or viewing the 
body is not possible immediately after death, the delay should be explained. While viewing the body matters for some people, others felt that it might interfere with their memory of the living person. Professionals, such as those working in emergency rooms, need to tell bereaved people about their options and meet the needs of the individual, allowing relatives to view the body, or part of the body, if they are sure that this is what they want.

Our findings have implications for funeral directors too. They may try to disguise injuries and present the body to the relatives as the person was in life, and, as some of our respondents suggested, skilfully applied makeup can help. But for best results those working in this profession must try to find out how a person had his or her hair in life, and how a woman might have applied her makeup. Sally's account (above) illustrates how an abnormal hairstyle or unusual makeup after death can become a focus for a relative's distress instead of making things better.

The aftermath of a traumatic death or suicide is inevitably a distressing time with lasting consequences. Professionals need to be sensitive to the different needs and preferences of people bereaved by traumatic death and to the social, familial, cultural, and legal context of the death. Clinicians should not assume that relatives will necessarily be harmed by seeing a bruised or damaged body. Some people may see the dead body as an empty shell, but others keep a bond with the social identity of the person, and they may see the body as continuing to harbour a spirit or at least some "lingering energy." The language used by people who have been bereaved offers a powerful clue to the nature of their sense of relationship with the dead body. We therefore encourage professionals to pay attention to how family members refer to the body: if they talk about it by name or use a personal pronoun this should alert clinicians to the continuing sense of social bond, and it would be advisable to follow suit rather than speak of the "body," "remains," or "deceased" and risk offence.

We thank the people who took part in the interviews, our multidisciplinary advisory panel, and all those who helped us to recruit. We also thank Andrew Herxheimer, Alexandra Pitman, Annette Braunack-Mayer, and Emmie Arnold for their help with earlier drafts of this article. Contributors: AC conducted the interviews. AC and SZ analysed the data. $\mathrm{AC}$ drafted the paper; $\mathrm{AC}$ and $\mathrm{SZ}$ contributed to the subsequent drafts and final version. AC and SZ will act as guarantors for the work. Funding: The Department of Health funded the work. The views expressed do not necessarily reflect those of the funder. Competing interests: None declared.

Ethical approval: Ethics committee approval was given for this study by Eastern MREC, Papworth Hospital NHS Trust, Papworth Everard, Cambridge. All participants gave informed consent before taking part and have given written consent to their interview data being included in publications
1 Machin L. In the last analysis. Community Care 1982;20:14-5.

2 Foltyn JL. The corpse in contemporary culture: identifying, transacting, and recording the dead body in the twenty-first century. Mortality 2008;13:2,99-104.

3 Bogard W. Empire of the living dead. Mortality 2008;13:2,187-200.

4 Hallam E, Hockey J, Howarth G. Beyond the body: death and social identity. Routledge, 1999.

5 Howarth G. Death and dying: a sociological introduction. Polity Press, 2007.

6 Douglas M. Purity and danger: an analysis of concepts of pollution and taboo. Routledge \& Kegan Paul, 1966.

7 Tye C. Qualified nurses' perceptions of the needs of suddenly bereaved family members in the accident and emergency department. J Adv Nurs 1993;18:948-56.

8 Cooke MW, Cooke HM, Glucksman EE. Management of sudden bereavement in the accident and emergency department. $B M$ J 1992;304:1207-9.

9 Hallam E, Hockey J. Death, memory and material culture. Berg, 2001.

10 Dix P. Access to the dead: the role of relatives in the aftermath of disaster. Lancet 1998;352:1061-2.

11 Worden JW. Grief counselling and grief therapy: a handbook for the mental health practitioner. 2nd ed. Routledge, 1991.

12 Paul R. Viewing the body and grief complications: the role of visual confirmation in grief reconciliation. In: Cox G, Bendiksen $R$, Stevenson R, eds. Complicated grieving and bereavement: understanding and treating people experiencing loss. Baywood, 2001.

13 Walter T. A new model of grief: bereavement and biography. Mortality 1996;1:7-25.

14 Silverman PR, Klass D, Nickman S. Introduction: what's the problem? In: Klass D, Silverman R, eds. Continuing bonds: new understandings of grief. Taylor and Francis, 1996.

15 Singh B, Raphael B. Post disaster morbidity of the bereaved: a possible role for preventative psychiatry? I Nerv Ment Dis 1981;169:203-12.

16 Hodgkinson P, Joseph S, Yule W, Williams R. Viewing human remains following disaster: helpful or harmful? Med Sci Law 1993;33:197-202.

17 Hodgkinson P. Viewing the bodies following disaster: does it help? Bereavement Care 1995;14:2-4.

18 Herxheimer A, Ziebland S. The DIPEx project: collecting personal experiences of illness and health care. In: Hurwitz B, Greenhalgh T, Skultans V, eds. Narrative research in health and illness. Blackwell, 2004:115-31.

19 Pope C, Ziebland S, Mays N. Qualitative research in health care: analysing qualitative data. BMJ 2000;320:114-6.

20 Coyne I. Sampling in qualitative research. Purposeful and theoretical sampling; merging or clear boundaries? J Adv Nurs 1997;26:623-30.

21 Glaser B, Strauss A. The discovery of grounded theory. Aldine Publishing, 1967.

22 Green J, Thorogood N. Qualitative methods for health research. Sage, 2004.

23 QSR International Pty: Melbourne, 2000.

24 Blumer H. Symbolic interactionism: perspective and method. Prentice Hall, 1969.

25 Valentine C. Bereavement narratives: continuing bonds in the twentyfirst century. Routledge, 2008.

26 Turner B. The body and society, 3rd ed. Sage, 2008.

27 Howarth G. Dismantling the boundaries between life and death. Mortality 2000;2:127-38.

28 Baglow J. The rights of the corpse. Mortality 2007;12:223-38.

29 Silverman D. Interpreting qualitative data. Sage, 1994.

30 Mowll J. Reality and regret: viewing or not viewing the body after a sudden death. Bereavement Care 2007;26:3-6.

31 Stroebe M, Gergen M, Gergen K, Stroebe W. Broken hearts or broken bonds? In: Klass D, Silverman P, Nickman S, eds. Continuing bonds: new understandings of grief. Taylor and Francis, 1996:31-44.

32 Awoonor-Renner S. Managing sudden bereavement. BM 1992;304:1566.

Accepted: 3 March 2010 